\title{
Age of Teachers Vs ICT use in Tanzanian Secondary Schools: A Case of Dodoma Municipality
}

\author{
Adam Mazoya \\ College of Informatics and \\ Virtual Education, \\ University of Dodoma, \\ Dodoma, Tanzania
}

\author{
Abbas Ismail \\ College of Mathematical and \\ Natural Sciences, \\ University of Dodoma, \\ Dodoma, Tanzania
}

\author{
Majuto Manyilizu \\ College of Informatics and \\ Virtual Education, \\ University of Dodoma, \\ Dodoma, Tanzania.
}

\begin{abstract}
The use of Information and Communication Technology (ICT) in teaching and learning has been the main target for public and private schools in Tanzania since the beginning of the $21^{\text {st }}$ century. Since then, however, the achievement of using ICT on teaching and learning has been relatively unsatisfactory due to several reasons including incompetence and poor understanding of teachers on ICT. This study intends to understand ICT literacy level, use of ICT tools in delivering contents, and readiness to adopt new methods of teaching and learning using ICT among secondary schools teachers with respect to their ages and level of education. The study was carried out in Dodoma municipality in central Tanzania for both government and private secondary schools. Questionnaires facilitated the survey methodology by involving sixteen (16) government and private secondary schools with study sample of 231 teachers. The results show that there is a positive relationship on age of teachers towards their ICT literacy. Furthermore, the study reveals that there is a significant difference between age of teachers and their highest level of education. Contrary, the findings reveal that; age is not a factor on teachers' use of ICT tools in delivering contents, and the readiness of teachers in adopting new methods of teaching and learning using ICT. Such results provide school administration and Tanzania government a clear way on how to use and build capacity of teachers in different ways of using ICT by considering teachers' age.
\end{abstract}

\section{General Terms}

ICT use, age of teachers

\section{Keywords}

Tanzania, Dodoma municipality, age, ICT literacy level, ICT tools, level of education, Secondary school teachers

\section{INTRODUCTION}

Information and Communication Technology (ICT) has proven to be a valuable aid in solving problems and accomplishing tasks in business, industry, government, education, and many other human endeavors (Moursund, 2005). Through the use of ICT, teaching and learning resources become attractive and flexible for both teachers and students. This technology has the power to change the daily practices of teaching staff as well as students. For example, Crawford (2003) highlighted that multimedia which is a mean of constructing flexible and attractive teaching and learning resources that integrate text, pictures, animation, video and sound can be used to improve teaching and learning. Thus, the use of ICT plays a critical role in education by mainly contributing on how knowledge is being transmitted from teaching staff to students.

Normally, countries redesign and reconstruct their educational policy and systems based on the current educational paradigms for both teachers and students. Such policies and systems are used to develop the necessary knowledge and skills sought in this ICT era. On improving education quality, ICT programs are integrated in education curriculum. However, Benzie (1995) indicates that national programs have not been so successful to implement ICT into educational systems because they were formulated in non-educational realms without support from educational research (Elisha and Kennedy, 2015).

The integration of ICT into education has been assumed as the potential of the new technological tools to revolutionize an outmoded educational system (Albrini, 2006). ICT has very strong effect in education as it provides enormous tools for enhancing teaching and learning. Thus, there have been many studies that have highlighted various ways that ICT may support teaching and learning processes in a range of different disciplinary fields such as the construction of new opportunities for interaction between students and knowledge, and accessing information. ICT can have a useful effect on teaching and learning if it is used under right conditions including suitable sources, training and support. ICT also offers the potential to meet the learning needs of individual students, to promote equal opportunity, to offer learning material, and also promote interdependence of learning among learners (Leach et al - 2005).

Roblyer and Edwards (2000) suggested that there are five important reasons for teachers to use technology in education: (1) motivation, (2) distinctive instructional abilities, (3) higher productivity of teachers, (4) essential skills for the Information Age, and (5) support for new teaching techniques. In order to use technology in the classroom effectively, teachers' attitude toward technology should be positive in conjunction with training on using the modern technologies in the field of education. Chin and Hortin (1994) stated that the teacher must clearly act as the change agent in the relationship between technology and the student. In a study by Jennings and Onwuegbuzie (2001), it was declared that younger teaching staff were found to have more positive attitudes towards the use of ICT. Also in the same context, Oscarson (1976) found that age is in a positive relationship with the attitude towards technologies, where older teaching staff were more adoption prone than younger teaching staff. The same view shared by Deniz (2005) determines that teachers' age was significantly related to teachers' attitudes with age of 36 being a "breaking point" for the positive attitudes of primary school teachers (Bulent at el. 2009).

The introduction of ICT in the Tanzanian education systems, particularly in pre-primary, primary and secondary schools has a very recent past. Books in schools libraries, blackboards and other traditional learning or instructional instruments still play a major role as the principal teaching resources in a good number of secondary and primary schools, specifically those 
in rural areas. The first attempt to introduce computers to Tanzania schools was done in 2003 by the initiation of a Tanzania National ICT Policy; its vision is to enable Tanzania become a hub of ICT infrastructure and ICT solutions that enhance sustainable socio-economic development and accelerated poverty reduction both nationally and globally (MoCT 2003). Tanzania Development Vision 2025 (GovTz 1999) also puts a great emphasis on the use of ICT as central part to competitive social and economic transformation. Since ICT is a cross-cutting tool, this policy was also linked to ICT activities in other areas and sectors, especially Vocational Training, Higher Education, Regional Administration and Local Government. The Ministry of Education and Vocational Training (MoEVT) has developed this policy to guide the integration of ICT in basic education. The policy covers preprimary, primary and secondary schools as well as teachers colleges in addition to non-formal and adult education. It is guided by the overall objectives of education policies, and relevant national development policies including the Tanzania National ICT Policy of 2003.

In spite of such emphasis, Senzige and Sarukesi (2003) point out that most schools even those that have some ICT facilities do not use them as learning and teaching tools (Mwalongo, 2011). The implementation of technology into the Tanzanian educational system has not been taken into consideration by enough research projects. It has been observed that in most ICT implementation cases 'teachers' age versus: their ICT literacy level, use of ICT tools in delivering contents, readiness to adopt and learn ICT methods for teaching, and their level of education" have not been investigated sufficiently in the early stages. According to Rogers's theory of diffusion of innovation, teachers' attitudes are indispensable to the innovation-decision process (Rogers, 1995). Thus, this study seeks to provide information that will assist on decision regarding ICT-related curricular and instructional matters through public and private secondary schools in Dodoma municipality as case study. The region has been used as an area of study because of the challenges it faces when considering secondary schools national examination results. At the national level, such results are repeatedly poor in the region (GoT, 2011).

The Tanzanian education curriculum requires all secondary school teachers to have necessary knowledge and skills not only on their area of specialization, but also on technology as well. The tendency in favor of or against using ICT in teaching and learning strongly depends on the factors like ICT literacy of teachers, age of teachers, their readiness to adopt new methods of teaching and learning and attitudes of teachers towards ICT use. Thus, the present study aims at investigating the influence of age among Tanzania secondary schools teachers and their attitudes toward ICT. The following hypotheses will, therefore, guide the study:

(1) There is no significant difference between age of secondary school teachers and their level of education

(2) There is no significant difference between age of secondary schools teachers and their ICT literacy

(3) There is no significant relationship between age of secondary schools teachers and their use of ICT tools in delivering contents.

(4) There is no significant difference on readiness to adopt new methods of teaching and learning ICT between age of secondary schools teachers
This introductory part comprises of four sections; the first section introduces the importance of the study, the next part goes through literature review followed by the studies case, and the last section reveals the hypotheses that guide the study. The rest of the paper is in methodology (Section 2) being followed by results and discussion (Section 3) and it ends with conclusion (Section 4).

\section{METHODOLOGY}

This section presents the methodology that has been adopted to conduct this study. It includes the study design, sampling, data collection techniques, study variables and methods of analysis.

\subsection{Study Design}

This study employed a cross-sectional descriptive design. This method was used to allow the researchers to have vivid description of how Tanzania secondary school teachers are making use of ICTs on basis of their ages. The questionnaire enquires information on teachers' demographic variable and ICT use background, their level of education and readiness to adopt and learn new technology.

\subsection{Sampling and Data Collection}

The targeted population for this study was Tanzania secondary school teachers, and Dodoma municipality was used as a case study. Stratified random sampling was used to obtain data from 7 private and 9 public secondary schools in the municipal with a total of 15 private and 37 government secondary schools. This makes a total of 52 schools in Dodoma municipality (Dodoma regional report, 2014). The schools were selected carefully basing on their levels (low, medium, high) of socio-economic status. Two hundred and thirty one teachers (120 male and 111 females) filled in survey questionnaires. The respondents cut across all professional status, subject discipline and age groups.

\subsection{Study Variables}

On the process of analyzing data, the outcome variables was taken to be the age group of teachers (age vs. level of education, age vs. ICT literacy, age vs. use of ICT tools in delivering contents, age vs. readiness to adopt new methods of teaching and learning using ICT). However, the independent variables (covariates) were; attendance of teachers to any ICT related course or taking a course at the University/College in ICT, use of ICT in content delivery, readiness to use ICT if empowered with necessary skills and technology, and maximum level of education reached by teachers.

\subsection{Methods of Studying and Analysis}

The quantitative and qualitative data collected during the study were analyzed with a Pearson chi-square using a statistical package IBM SPSS 22. This method compares the binary outcome and other independent variables.

In formulating the study, the following null hypotheses were considered and tested at $5 \%$ level of significance.

Study hypothesis 1: There is no significant difference between age of secondary school teachers and their level of education.

Study hypothesis 2: There is no significant difference between age of secondary schools teachers and their ICT literacy. 
Study hypothesis 3: There is no significant relationship between age of secondary schools teachers and their use of ICT tools in delivering contents.

Study hypothesis 4: There is no significant difference on readiness to adopt new methods of teaching and learning ICT between ages of secondary schools teachers.

\section{RESULTS AND DISCUSSION}

This section explains the results obtained during the study. It begins by describing the characteristics of the participants and then proceeds to analysis of the hypotheses. At the end of the section there is a critical discussion of the results.

\subsection{Profile of Respondents and Schools}

The descriptive profile of the respondents and schools in this study is shown on Table 1. The respondents are described in terms of sex, age, maximum level of education, number of years in the teaching carrier and the type of schools which they teach. The population of this study comprised a total of 231 teachers with 120 males and 111 females. Respondents were asked also to tell which type of subjects they teach and level of teaching (ordinary level, advanced level or others).

From Table 1, it can be observed that the number of male respondents exceeded that of female respondents by 9 . Age wise, the majority of the respondents came from the age group 26 - 35 years $(64.5 \%)$ while the least represented group was the age group $18-25$ years $(6.9 \%)$. It is also noted that the majority of respondents were bachelor degree holders $(75.8 \%)$ followed by diploma $(22.9 \%)$, certificate $(0.9 \%)$ and form six $(0.4 \%)$. Many respondents came from a category of those having less than 5 years of teaching experience $(43.7 \%)$ followed by $5-10$ years $(37.2 \%), 11-20$ years $(10.4 \%), 21-30$ years $(5.2 \%)$ and the least represented group was the group with more than 30 years in the teaching carrier description $(3.5 \%)$. Such number of respondents with diversity characteristics provides useful results on age of secondary school teachers against using ICT on learning and teaching in Tanzania.

\subsection{Age of Teachers Vs. ICT}

This study focuses on understanding relationship of age of secondary school teachers against ICT in different aspects. The results have been summarized in Table 2 and 3 after running a Chi-square test to test the significance between range of age of teachers and the hypotheses representing their use of ICT in teaching and delivering contents. Table 2 represents the results obtained during data analysis using a statistical package IBM SPSS 22 with p-value at a significance level of 5\%. This table represents the findings that address hypotheses two and three. The results are discussed below in relation to teachers'; level of education, ICT literacy, and use of ICT tools in delivering contents as well as teacher's readiness to adopt new methods of teaching and learning ICT

\subsubsection{Teachers' age Vs. level of education. and ICT literacy}

The age of the secondary school teachers was studied against their highest level of education. This was achieved by addressing the first hypothesis which states that: There is no significant difference between age of secondary school teachers and their level of education. The first null hypothesis was not retained because there is a significant relationship between secondary school teachers' level of education and their ages. Fisher's Exact Test and p-value $(0.030, \mathrm{p}<0.05)$ support this decision.
The second hypothesis which states that: there is no significant difference between age of secondary schools teachers and their ICT literacy, provides relation between the age of secondary school teachers and ICT literacy. In this hypothesis, the null hypothesis was rejected. Thus, age of secondary schools teachers is an important factor for their ICT literacy. The corresponding Chi-square value and p-value (Chi square $=0.012, \mathrm{p}<0.05$ )

The results show that age is an important factor when considering levels of education and ICT literacy among Tanzania secondary school teachers. Group age of $26-35$ carries the most educated group of teachers with bachelor degree or above. Our study also shows that this group is the most ICT literate group.

\subsubsection{Teachers' age Vs. use of ICT tools and readiness for new educational technologies}

The competent use of ICT tools in delivering teaching and learning contents is very important for proper ICT utilization in education. This aspect has been studied in this paper through the third hypothesis. The null hypothesis was retained with the corresponding Chi-square value and p-value (Chi square $=0.905, \mathrm{p}>0.05$ ). Thus, ages of a secondary school teachers are not a factor when comes to teachers' use of ICT tools in delivering contents.

To understand the relation between ages of secondary school teachers and their readiness to adopt new methods of teaching and learning ICT among secondary schools teachers, hypothesis four was used. The hypothesis states that there is no significant difference on readiness to adopt new methods of teaching and learning ICT between ages of secondary schools teachers. Through this hypothesis, the study fails to reject this hypothesis. Fisher's Exact Test and p value (0.491, $\mathrm{p}>0.05$ ) which means, therefore, that readiness to adopt new methods of teaching and learning ICT does not depend to ages of secondary school teachers.

The third and fourth hypotheses show commonality in null hypothesis. The null hypothesis three and four accordingly shows that age is not a factor among secondary school teachers' in Tanzania (Dodoma) when considering teachers' use of ICT tools in delivering contents and their readiness to adopt new methods of teaching and learning ICT.

Table 3 shows the results obtained during data analysis using a statistical package IBM SPSS 22, using Fisher's Exact Test value at a $95 \%$ significant level. Using these results from Table 3, the study reveals the findings that respond to the study questions from hypothesis one and four.

The Chi-square together with statistical p-values as well as Fisher's Exact test value were calculated, the results of crosstabulation are presented in Table 2 and Table 3 to test the hypotheses proposed.

Table1: Characteristics of the participants

\begin{tabular}{|l|l|l|l|}
\hline Covariate & Response & Frequencies & Percentage \\
\hline \multirow{3}{*}{ Sex } & Male & 120 & 51.9 \\
\cline { 2 - 4 } & Female & 111 & 48.1 \\
\hline \multirow{3}{*}{ Age } & $18-25$ & 16 & 6.9 \\
\cline { 2 - 4 } & $26-35$ & 149 & 64.5 \\
\cline { 2 - 4 } & $36-45$ & 43 & 18.6 \\
\hline
\end{tabular}




\begin{tabular}{|c|c|c|c|}
\hline & Above 45 & 23 & 10.0 \\
\hline \multirow{4}{*}{$\begin{array}{l}\text { Maximum } \\
\text { level of } \\
\text { education } \\
\text { reached }\end{array}$} & Form VI & 1 & 0.4 \\
\hline & Certificate & 2 & 0.9 \\
\hline & Diploma & 53 & 22.9 \\
\hline & $\begin{array}{l}\text { Bachelors } \\
\text { degree }\end{array}$ & 175 & 75.8 \\
\hline \multirow{5}{*}{$\begin{array}{l}\text { Number of } \\
\text { years in the } \\
\text { teaching } \\
\text { carrier }\end{array}$} & $\begin{array}{l}\text { Less than } \\
5 \text { years }\end{array}$ & 101 & 43.7 \\
\hline & $\begin{array}{ll}5- & 10 \\
\text { years } & \end{array}$ & 86 & 37.2 \\
\hline & $\begin{array}{l}11-20 \\
\text { years }\end{array}$ & 24 & 10.4 \\
\hline & $\begin{array}{l}21-30 \\
\text { years }\end{array}$ & 12 & 5.2 \\
\hline & $\begin{array}{l}\text { More than } \\
30 \text { years }\end{array}$ & 8 & 3.5 \\
\hline \multirow{2}{*}{$\begin{array}{l}\text { Distribution } \\
\text { of the type } \\
\text { of school }\end{array}$} & $\begin{array}{l}\text { Public } \\
\text { schools }\end{array}$ & 9 & 44 \\
\hline & $\begin{array}{l}\text { Private } \\
\text { schools }\end{array}$ & 7 & 56 \\
\hline \multirow{3}{*}{$\begin{array}{l}\text { Type of } \\
\text { subjects } \\
\text { taught }\end{array}$} & $\begin{array}{l}\text { Science } \\
\text { subjects }\end{array}$ & 54 & 23,6 \\
\hline & $\begin{array}{l}\text { Arts } \\
\text { subjects }\end{array}$ & 157 & 68,6 \\
\hline & Business & 15 & 6,6 \\
\hline
\end{tabular}

\begin{tabular}{|l|l|l|l|}
\hline \multirow{2}{*}{} & subjects & & \\
\cline { 2 - 4 } & Other & 3 & 1,3 \\
\hline $\begin{array}{l}\text { Level of } \\
\text { teaching }\end{array}$ & $\begin{array}{l}\text { ordinary } \\
\text { level }\end{array}$ & 209 & 91,3 \\
\cline { 2 - 4 } & $\begin{array}{l}\text { advanced } \\
\text { level }\end{array}$ & 18 & 7,9 \\
\cline { 2 - 4 } & others & 2 & 0,9 \\
\hline
\end{tabular}

Table 1: Age vs. Teacher's ICT literacy and Teacher's use of ICT tools in delivering contents

\begin{tabular}{|c|c|c|c|c|c|c|}
\hline \multirow[t]{2}{*}{ Covariate } & \multirow{2}{*}{$\begin{array}{l}\text { Res } \\
\text { pon } \\
\text { se }\end{array}$} & \multicolumn{4}{|c|}{ Age in years } & \multirow{2}{*}{$\begin{array}{l}\text { p- } \\
\text { val } \\
\text { ue }\end{array}$} \\
\hline & & $18-25$ & $\begin{array}{l}26- \\
35\end{array}$ & $36-45$ & $\begin{array}{l}\text { Abov } \\
\text { e } 45\end{array}$ & \\
\hline \multirow{2}{*}{$\begin{array}{l}\text { Have } \\
\text { attended any } \\
\text { ICT related } \\
\text { course? OR } \\
\text { Have you taken } \\
\text { a course at the } \\
\text { University } \\
\text { /college in } \\
\text { ICT? }\end{array}$} & Yes & $\begin{array}{l}10 \\
(76.9 \%)\end{array}$ & $\begin{array}{l}101 \\
(80.2 \\
\%)\end{array}$ & $\begin{array}{l}21 \\
(58.3 \\
\%)\end{array}$ & $\begin{array}{l}9 \\
(52.9 \\
\%)\end{array}$ & \multirow{2}{*}{$\begin{array}{l}0.0 \\
12\end{array}$} \\
\hline & No & $\begin{array}{l}3 \\
(23.1 \%)\end{array}$ & $\begin{array}{l}25 \\
(19.8 \\
\%)\end{array}$ & $\begin{array}{l}15 \\
(41.7 \\
\%)\end{array}$ & $\begin{array}{l}8 \\
(47.1 \\
\%)\end{array}$ & \\
\hline \multirow{2}{*}{$\begin{array}{lr}\text { In } & \text { your } \\
\text { teaching, do } \\
\text { you use any } \\
\text { ICT tool in } \\
\text { delivering } \\
\text { content? }\end{array}$} & Yes & $\begin{array}{l}9 \\
(56 \%)\end{array}$ & $\begin{array}{l}84 \\
(56.8 \\
\%)\end{array}$ & $\begin{array}{l}20 \\
(46.5 \\
\%)\end{array}$ & $\begin{array}{l}12 \\
(52.2 \\
\%)\end{array}$ & \multirow[t]{2}{*}{$\begin{array}{l}0.9 \\
05\end{array}$} \\
\hline & No & $\begin{array}{l}7 \\
(44 \%)\end{array}$ & $\begin{array}{l}63 \\
(42.6 \\
\%)\end{array}$ & $\begin{array}{l}23 \\
(53.5 \\
\%)\end{array}$ & $\begin{array}{l}11 \\
(47.8 \\
\%)\end{array}$ & \\
\hline
\end{tabular}

Table 2: Teachers' age vs. teacher's level of education and teachers' readiness to adopt new methods of teaching and learning ICT

\begin{tabular}{|c|c|c|c|c|c|c|}
\hline \multirow[t]{2}{*}{ Covariate } & \multirow[t]{2}{*}{ Response } & \multicolumn{4}{|c|}{ Age in years } & \multirow{2}{*}{$\begin{array}{l}\text { Fisher's } \\
\text { Exact Test }\end{array}$} \\
\hline & & $18-25$ & $26-35$ & $36-45$ & Above 45 & \\
\hline \multirow{4}{*}{$\begin{array}{l}\text { Maximum level of } \\
\text { education reached }\end{array}$} & form six & $\begin{array}{ll}0 & (0 \%)\end{array}$ & $1 \quad(0.7 \%)$ & $\begin{array}{ll}0 & (0 \%)\end{array}$ & $0 \quad(0 \%)$ & \multirow{4}{*}{0.030} \\
\hline & certificate & $(6.3 \%)$ & $\begin{array}{ll}1 & (0.7 \%) \\
\end{array}$ & $\begin{array}{ll}0 & (0 \%) \\
\end{array}$ & $0 \quad(0 \%)$ & \\
\hline & diploma & $\begin{array}{ll}6 & (37.5 \%) \\
\end{array}$ & $25 \quad(16.8 \%)$ & $\begin{array}{ll}13 & (30.2 \%) \\
\end{array}$ & $\begin{array}{ll}9 & (39.1 \%) \\
\end{array}$ & \\
\hline & degree or above & $(56.3 \%)$ & $122(81.9 \%)$ & $\begin{array}{ll}30 & (69.8 \%) \\
\end{array}$ & $14 \quad(60.9 \%)$ & \\
\hline \multirow{2}{*}{$\begin{array}{l}\text { If you do not use any } \\
\text { ICT tool in delivering } \\
\text { content, are you ready } \\
\text { to use if empowered } \\
\text { with skills and } \\
\text { technology? }\end{array}$} & Yes & $11(84.6 \%)$ & $96 \quad(88.9 \%)$ & $25(100 \%)$ & $15 \quad(93.8 \%)$ & \multirow{2}{*}{0.491} \\
\hline & No & $\begin{array}{ll}1 & (7.7 \%)\end{array}$ & $\begin{array}{ll}9 & (8.3 \%)\end{array}$ & $0 \quad(0 \%)$ & $\begin{array}{ll}1 & (6.2 \%)\end{array}$ & \\
\hline
\end{tabular}

In summary, age of secondary schools teachers is an important factor to teachers' ICT literacy as attributed to the tendencies of group of young teachers to attend ICT related courses or studying courses at the University/College in ICT. Also there is an association on level of education reached by a teacher and teacher's age, (Table 2 and Table 3). Use of ICT tools in delivering contents as well as readiness to adopt new methods of teaching and learning ICT between secondary school teachers in Tanzania does not depend on the teachers' ages (Table 2 and Table 3 ).

\section{CONCLUSION}

This empirical study intended to understand relationship between age of secondary school teachers in Tanzania (Dodoma municipality was used as a case study) and their ICT use in following aspects: teachers' level of education, ICT literacy, use of ICT tools in delivering contents as well as teacher's readiness to adopt new methods of teaching and learning ICT.

This study indicates that readiness to adopt new methods of teaching and learning ICT and use of ICT tools in delivering contents between ages of secondary schools teachers in Tanzania, age is not a factor. Contrary, the study shows that 
there is a significant difference between ages of secondary school teachers and their maximum level of education as age groups of $26-35$ years followed by $36-45$ years represent the most educated teachers while a group of $18-25$ years carries the most junior teachers when considering their maximum level of education. The study has also revealed that there is a significant difference between ages of secondary school teachers and their ICT literacy as the findings indicate that secondary school teachers in the group ages of $26-35$ being followed by $18-25$ appears to be more ICT knowledgeable than other groups with older ages. This study concludes that in considering ICT literacy level and level of education reached by secondary school teachers in Tanzania, age is a significant factor as group age $26-35$ represents the most educated group and the same group has most ICT knowledgeable teachers. This shows that the more a teacher advances his/her level of education the more her/his ICT literacy improves.

The findings above suggest that the government should put more emphasis on setting up ICT infrastructures in public schools. The government also should further train teachers in public schools through in-service trainings to equip them with skills on how better they should utilize ICT infrastructure for content delivery. Also workshops/seminars should be organized specifically for the purpose of facilitating teacher's literacy, awareness and skills on using ICT in delivering contents, as this will largely enhance the capacity of Tanzania secondary school teachers in ICT utilization.

\section{ACKNOWLEDGEMENT}

Special thanks to the Carnegie-SIG Regional Initiative in Science and Education (RISE) through its competitive fund award for supporting this research. Special thanks to Computation and Modelling Research Group at University of Dodoma for the support on technical and academic issues regarding this publication. Moreover, this study wouldn't have been possible without a generous support from headmasters, headmistress and teachers of secondary schools in Dodoma municipality.

\section{REFERENCES}

[1] Moursund, D. (2005) Introduction to Information and Communication Technology in Education.

[2] Crawford, R. (2003) Managing information technology in secondary schools

[3] Elisha, C. K. and Kennedy, A. T. (2015) Integrating ICT in Instructional Design - Meeting the Needs of a Distributed Learning Environment at Zimbabwe Government Correspondence School (ZGCS). International Journal of Science and Research (IJSR) ISSN (Online): 2319-7064
[4] Albirini, A. (2006) Teachers' attitudes toward information and communication technologies: the case of Syrian EFL teachers. Computers and Education, 47(4), 373-398

[5] Robyler, M. D. and Edwards, J. (2000). Integrating educational technology into teaching and learning (2nd ed.). Upper Saddle River, NJ: Prentice-Hall.

[6] Chin, S. \& Hortin, J.A. (1994). Teachers' perceptions of instructional technology and staff development. Journal of Educational Technology Systems, 22(2) 83-98

[7] Jennings, S. E., and Onwuegbuzie, A. J. (2001). Computer attitudes as a function of age, gender, math attitude, and developmental status. Journal of Educational Computing Research, 25 (4), 367 - 384

[8] Oscarson, D. (1976). Factors associated with vocational teacher proneness toward the adoption of innovations. Unpublished doctoral dissertation, Virginia Polytechnic Institute and State University.

[9] Deniz, L. (2005). İlköğretim Okullarında Görev Yapan Sınıf ve Alan Öğretmenlerinin Bilgisayar Tutumları. The Turkish Online Journal of Educational Technology. 4(4). Retrieved from www.tojet.net

[10] Bulent C., Pınar C., Bahar K. and Tarik K. (2009). A Study on Science Teachers' Attitudes Toward Information and Communication Technologies in Education. The Turkish Online Journal of Educational Technology - TOJET April 2009 ISSN: 1303-6521 volume 8 Issue 2 Article 2

[11] The United Republic of Tanzania Ministry of Communications and Transport, National Information and Communications Technologies Policy (MoCT 2003, p. 2)

[12] Government of Tanzania, 1999. Vision 2025

[13] Senzige, J. P, and Sarukesi, K (2003) An Approach to ICT based school education in Tanzania,. African Studies Association of Australasia and the Pacific 2003 Conference Proceedings - African on a Global Stage

[14] Rogers, E. M. (1995). Diffusion of innovations (4th ed.). New York: London: Free Press

[15] Government of Tanzania, Certificate Of Secondary Education Examination (CSEE) - 2011, Report And Analysis Of The Results

[16] Dodoma Regional report to the President of the United Republic of Tanzania, August, 2014 